\title{
Comparative research of dominant leadership styles in large enterprises in the Republic of Croatia*
}

Keywords: dominant leadership style, large enterprises, the Republic of Croatia

\section{Introduction}

The numerous leadership theories have been developed at the end of the last century and the beginning of the $21^{\text {st }}$ century trying to give a "universal" response on question "whatmakes good leadership?" from their angle. Therefore, every new theory was a reaction to the current ones and their main goal was to avoid the disadvantages of the previous theories. In search of the answer, important leadership theories arose - from the personality theory, through behaviorist and contingency theories, to the theory of transformational and transactional leadership. Through years numerous definitions of leadership have appeared:

- leadership may be considered as the process (act) of influencing the activities of an organized group in its efforts toward goal setting and goal achievement (Stogdill, 1950, p. 3),

- leadership is the behavior of an individual when they are directing the activities of a group toward a shared goal (Hemphill, Coons, 1957, p. 7),

* Associate professor Ivona Vrdoljak Raguž, PhD, University of Dubrovnik, Department of Economics and Business Economics, Croatia, e-mail: ivona.vrdoljak@unidu.hr

** This paper is a part of the project under the title: Strategy of Corporation - present future (Search for possibilities of growth companies in the Republic of Croatia), Leader: Professor Ivan Mencer, Project funded: The University of Rijeka. 
- leadership is interpersonal influence, exercised in a situation, and directed through the communication process toward the attainment of a specified goal or goals (Tannenbaum et al., 1961, p. 24)

- leadership is the initiation and maintenance of structure in expectation and interaction (Stogdill, 1974, p. 411),

- leadership is a process of influence between a leader and those who are followers (Hollander, 1978, p. 1),

- leadership is the influential increment over and above mechanical compliance with the routine directives of the organization (Katz, Kahn, 1978, p. 528),

- leadership is the process of influencing the activities of an organized group toward goal achievement (Rauch, Behling, 1984, p. 46),

- leadership is an attempt at influencing the activities of followers through the communication process and toward the attainment of some goal or goals (Donelly et al., 1985, p. 362),

- leadership is the process of influencing the activities of an individual or a group in efforts toward goal achievement in a given situation (Hersey, Blanchard, 1988, p. 86),

- leadership is an interaction between two or more members of a group that often involves a structuring or restructuring of the situation and the perceptions and expectations of members; leadership occurs when one group member modifies the motivation or competencies of others in the group; any member of the group can exhibit some amount of leadership (Bass, 1990, pp. 19-20),

- leadership is the art of influencing others to their maximum performance to accomplish any task, objective or project (Cohen, 1990, p. 9),

- leaders are individuals who establish direction for a working group of individuals who gain commitment from this group of members to this direction and who then motivate these members to achieve the direction's outcomes (Conger, 1992, p. 18),

- leadership requires using power to influence the thoughts and actions of other people (Zalenik, 1992),

- leadership is the art of mobilizing others to want to struggle for the shared aspirations (Kouzes, Posner, 1995, p. 30).

Taking these definitions, it becomes clear that most of the leadership definitions assume that "leadership is a process whereby intentional influence is exerted by one person over others in order to guide, structure and facilitate organizational activities and relationships" (Yukl, 2002, p. 7).

Without quality leadership and initiation of the members' activities, stimulation of high motivation and engagement of people, there is neither successful organization nor successful enterprise. Experience has shown that managerial efficiency differs depending 
on the managers' leadership style. This has stimulated numerous research that have tried to answer the question which leadership style is the best. Scientific research, up to now, of which most significant are the works of McGregor, Argyris, Likert, Blake and Mounton, Fiedler, House, towards the more current research of Taffinder, Crosby and Daft, have shown that leadership styles influence the efficiency of the enterprise on one hand, and performance and satisfaction of the subordinates on the other. Although there still is no uniform answer to the question of which leadership style is the most efficient, the research so far has shown that the leadership style is the cause, and not the consequence of the enterprise performance, and that there are significant differences in leadership, monitoring, interpersonal relationships, application of methods, communication and other management components between successful and unsuccessful managers, that is between organizational units of which they are at the head (Skansi, 2000, pp. 51-52).

In this paper the style approach has been chosen to investigate dominant leadership style. The style approach emphasizes the behavior of a leader and focuses exclusively on what leaders do and how they act. The style approach expanded the study of leadership to include the action of leaders towards subordinates in various contexts. Likert's model for analysis of organizations and leadership styles is used in the paper (Likert, 1961). Likert believed that the key to good leadership is to establish a climate and system of management that creates an effective organization. He examined different types of organizations and leadership styles, and he asserted that to achieve maximum profitability, good labor relations and high productivity, every organization must make optimum use of their human assets. Likert identified four main styles of leadership, in particular around decision-making and the degree to which people are involved in the decision (Vrdoljak Raguž, 2010):

1. Exploitive authoritative - system 1 (in this style, the leader has a low concern for people and uses such methods as threats and other fear-based methods to achieve conformance. Communication is almost entirely downwards and the psychologically distant concerns of people are ignored);

2. Benevolent authoritative - system 2 (when the leader adds concern for people to an authoritative position, a "benevolent dictatorship" is formed. The leader now uses rewards to encourage appropriate performance and listens more to concerns lower down the organization, although what they hear is often rose-tinted, being limited to what their subordinates think that the boss wants to hear. Although there may be some delegation of decisions, almost all major decisions are still made centrally);

3. Consultative - system 3 (the upward flow of information here is still cautious and rose-tinted to some degree, although the leader is making genuine efforts to listen carefully to ideas. Nevertheless, major decisions are still largely centrally made); 
4. Participative - system 4 (at this level, the leader makes maximum use of participative methods, engaging people lower down the organization in decisionmaking. People across the organization are psychologically closer together and work well together at all levels).

In this paper based on a survey research of large Croatian enterprises two main responses on two queries will be carried out:

1. What are the main specifics of top level managers' leadership style in large Croatian enterprises in 2008 and in 2015 ?

2. What leadership style is dominant by the size of the enterprise in large Croatian enterprises in 2008 and in 2015 ?

\section{Data analysis and research methodology}

Empirical research has been conducted on a population of large Croatian enterprises that have been percept as a generator of development of economy although the privatisation and restructuring of some large Croatian enterprises is still present.

Survey research has been conducted in this empirical research. Survey has been sent to top managers of the large Croatian enterprises. In 2008314 survey questionnaires were sent and 81 questionnaires were returned, which represents population of $25.8 \%$. In 2015350 survey questionnaires were sent and 94 questionnaires were returned. The questionnaire had 56 questions formulated to the Likert analytical method for analysis of organization and identification of dominant leadership style.

Likert's model has been used which is a satisfactory framework for the creation of scientific models for empirical research. Let us remember that in his research, Likert has two main starting points: there are significant differences in leadership, monitoring, interpersonal relations and other components of management between successful and unsuccessful managers, that is between organizational units which they are headed by, and management style which is the cause, not the consequence of organizational efficiency. Likert sees a successful manager as a person strongly oriented towards the subordinates, who relies on communication in maintaining a harmonious functioning of all parts. All group members, including the manager or a leader, adopt a supportive attitude whereby they participate in the common values, aspirations, goals and expectations. He stresses that a participational leadership system is the most efficient, a system which is based on high goals and requirements which activate individuals, develop their abilities through joint decision-making, decentralization of decisionmaking upon those levels at which there is more knowledge and information for quality decisions, and thus the greatest interest for decision-making. 
In the paper the diagnostic model is based on Likert's model. Managers have given the answers to the six variables that enactive the leadership styles and are included in the survey:

1. Leadership as a first variable of leadership style is measured with: reliability of the leader to the subordinates, freedom of subordinates in communication with the leader.

2. Motivation is measured with flow of information, types and formats of motives, responsibility for achieving goals and team work.

3. Communication in the enterprise is measured with these variables: flow of information, acceptance of information from employees, accuracy of information.

4. Decision making is measured with variables like levels of decision making, participation of employees in decision making and motivation of employees.

5. Goals are measured with the way of setting the goals and with resistance on settled goals.

6. Control is measured with the holder of control function, resistance of roles and purpose of control data.

The answers on these variables are from 1 to 4, and every answer corresponds to one of Likert's four leadership styles: System 1, System 2, System 3 and System 4.

Survey research was created to determinate top level manager's leadership style based on the six variables of leadership styles and average value of leadership styles.

Empirical results show that in $2008-66.67 \%$ and in $2015-72.35 \%$ of top level managers show reliability and trust to subordinates with a large liberty of communication with managers. Managers often accept ideas of subordinates (in $200870.37 \%$ and in $2015-75.35 \%$ ). The average scale is from 2.90 to 3.04 for both analyzed years so it can be interpreted as a consultative leadership style.

The second key variable for determination of leadership style is motivation that is closely connected with leadership. The survey results shown that managers use reward as a main form of motivation, $43.21 \%$ in 2008 and $45.25 \%$ in 2015 . with the average scale of leadership style between style 2 and style 3 . Form of motivation varies from economic and social to compliment and appreciation. The majority of managers holds both top and middle level managers important when is about achievement of goals. Team work is present in the whole organization.

The third variable is communication and its development in organizations. The usual way for receiving and giving information is in all directions. More than a half of surveyed managers think that information is mainly correct (77.78\% in 2008 and $75.24 \%$ in 2015). From this data it can be seen that subordinates are free to communicate with their managers. The average scale is between style 2 and style 3 . 
Decision making is the fourth variable of leadership style. Data for this variable have shown that managers in large Croatian enterprises are not autocratic leaders because $41.98 \%$ of managers delegate decisions on middle level management, so average scale of 2.54 has been expected in 2008 and $38.45 \%$ and style 2.35 in 2015 . Half of managers usually consulate their subordinates and when it comes to decentralization in organization, the data show that decentralization is present in $54.32 \%$ of enterprises in 2008 and $57.25 \%$ in 2015 .

The fifth key variable are the organizational goals. Consultative leadership style practices more than a half of managers in 2008 and 2015 when it comes to settlement of goals. Majority of managers analyze the business data on a monthly basis. This fact is very important because it implicates close connection between planning and controlling as two main managers' functions.

The sixth variable is control function. Data analysis shows that majority of surveyed managers think that managers at all management levels are responsible for control function (both in 2008 and 2015).

All this data have helped in determination and analysis of a dominant leadership style regarding the enterprise size.

\section{Research findings}

The findings of the research and the statistical results of the data gathered are presented below. The consultative leadership style is dominant in three categories regarding the enterprise size (250-500 employees, 501-750 employees and more than 3,001 employees). In all other categories leadership style is between paternalist and consultative leadership style. Managers that are working in large enterprises usually prefer rigid leadership style because of two main characteristics of leadership in large organizations: many employees and numerous management levels, while in small enterprises leadership styles are usually liberal ones with expressed delegation and involvement of employees in the decision making processes. It is interesting that there is no big difference between analysis of data in 2008 and 2015 (Table 1).

Table 1. Dominant leadership style regarding to enterprise size

\begin{tabular}{|l|c|c|c|c|c|c|c|}
\cline { 2 - 8 } \multicolumn{1}{c|}{} & \multicolumn{7}{c|}{ Large Croatian enterprises to the enterprise size } \\
\cline { 2 - 8 } \multicolumn{1}{c|}{} & $250-500$ & $501-750$ & $751-1,000$ & $1,001-1,250$ & $1,251-1,500$ & $1,501-3,000$ & $3,001-$ \\
\hline $\begin{array}{l}\text { Average dominant } \\
\text { leadership style in 2008 }\end{array}$ & 3.02 & 2.88 & 2.80 & 2.89 & 2.67 & 2.59 & 2.76 \\
\hline $\begin{array}{l}\text { Average dominant } \\
\text { leadership style in 2015 }\end{array}$ & 3.05 & 2.96 & 2.56 & 2.90 & 3.05 & 2.76 & 2.88 \\
\hline
\end{tabular}

Source: research results. 
Leadership style of top managers in large Croatian enterprises has shown different manifestation. Leadership style in large Croatian enterprises is closest to the system 4 in three situations, when it comes to motivation, acceptance of information from subordinates and frequency of requirements and realised goals analysis. Surveyed managers are closest to the system 1 when it comes to responsibility for realization of goals. Majority of managers think that top and middle managers are primarily responsible for setting the goals in the enterprise. The similar situation is with decision-making, where the majority of decision is in the top management. Other answers have shown that the dominant management style of surveyed managers is between system 2 and system 3 , but mostly system 3 .

\section{Discussion}

This paper aimed to find out what leadership style is the dominant leadership style in large Croatian enterprises. Results have shown that majority of managers in large enterprises prefer benevolent-authoritative and consultative leadership style. That can be explained with the fact that in large enterprises numerous experts work and problems that can appear are team work and its effort to achieve enterprise's goals. Other important factors are business environment, privatisation and transition processes. Some research have shown that small enterprises are more successful when is about organizational effectiveness.

Although the theory explains that leadership styles in large enterprises are more rigid than in other enterprises research results from this survey research have shown the opposite situation that can be explained with the fact that Croatian top managers are working in a large Croatian enterprise which is privatised and no longer in transition process (more than $90 \%$ of enterprises from the sample have private proprietary).

\section{Conclusion}

Diagnosis of leadership style is a very complex assignment, and because of this during the years a lot of models have been developed for the diagnosis of leadership style.

Analysis of variables of leadership style has shown that organizational behavior and praxis of leadership style of surveyed top managers in large Croatian enterprises is combination of benevolent-authoritative (system 2) and consultative leadership style (system 3) in both analyzed years in 2008 and 2015. It is obvious that top managers have to change some aspects of their leadership style from time to time, because there is no 
universal leadership style for all business situations. Top managers should evaluate and appreciate autocratic management style as well as democratic leadership style. Managers should turn to the employment, human potentials and establishment of "composite management" where there is an exceeding presence of women in management, because of their ethical approach to the colleagues and subordinates and when there is a strong tendency to paying attention to the organizational goals and organizational development.

The results of this research may serve as a motivation and an argument for application of the most efficient leadership style, so that the human potential would be used best by activating and developing the capabilities of every individual, to increase the flexibility and adaptive capabilities of an organization.

This paper can be considered as the foundation of furthered studies. It is believed that the identification of top level manager's leadership style has importance for organizations. Furthered studies will be understood better involving different dimensions and variables in the study.

\section{References}

Bass, B.M. (1990). Bass and Stogdill's handbook of leadership: Theory, research and managerial applications. New York: Free Press.

Cohen, W.A. (1990). The art of a leader. Englewood Cliffs. New Jersey: Jossey-Bass.

Conger, J.A. (1992). Learning to lead. San Francisco: Jossey-Bass.

Donelly, J.H., Ivancevich, J.M., Gibson, J.L. (1985). Organizations: behavior, structure, processes, 5th ed. Plano, Texas: Business Publications Inc.

Hemphill, J.K., Coons, A.E. (1957). Development of the leader behavior description questionnaire. In: R.M. Stodgill, A.E. Coons (eds.). Leader behavior: Its description and measurement. Columbus. Ohio: Bureau of Business Research, Ohio State University.

Hersey, P., Blanchard, K. (1988). Management of organizational behavior. Englewood Cliffs, New Jersey: Prentice Hall.

Hollander, E.P. (1978). Leadership dynamics: A practical guide to effective relationships. New York: Free Press.

Katz, D., Kahn, R.L. (1978). Social psychology of organizations, 2nd ed. New York: John Wiley. Kouzes, J.M., Posner, B.Z. (1995). The leadership challenge. San Francisco: Jossey-Bass.

Likert, R. (1961). New Patterns of Management. McGraw Hill, New York.

Rauch, C.F., Behling, O. (1984). Functionalism: Basis for an alternate approach to the study of leadership. In: J.G. Hunt, D.M. Hosking, C.A. Schriesheim, R. Stewart (eds). Leaders and managers: International perspectives on managerial behavior and leadership. New York: Pergamon Press.

Skansi, D. (2000). Relation of managerial efficiency and leadership styles - empirical study in Hrvatska elektroprivreda d.d., Management - Journal of Contemporary Management Issues, University of Split, Faculty of Economics, Split.

Stogdill, R.M. (1950). Leadership, membership and organization. Psychological Bulletin, 47 (1), $1-14$.

Stogdill, R.M. (1974). Handbook of leadership: A survey of the literature. New York: Free Press. 
Tannenbaum, R., Weschler, I.R., Massarik, F. (1961). Leadership and organization. New York: McGraw-Hill.

Zalenik, A. (1992). Managers and leaders: are they different? Harvard Business Review. March/ April.

Vrdoljak Raguž, I. (2010). Top Level Manager's Leadership Styles in Large Croatian Companies. Business Review, Cambridge, 14 (2), 154-160.

Yukl, G.A. (2002). Leadership in Organizations, Fifth Edition. Prentice Hall, Upper Saddle River, New York.

\begin{abstract}
The main goal of this paper is to present comparative analysis of dominant leadership styles in large Croatian enterprises. The research framework which examines leadership styles in large Croatian enterprises is based on the Likert analysis of organization and leadership styles. Survey research was conducted in 2008 and 2015. The result of the research reveals that the dominant leadership style in large Croatian enterprises regarding the enterprise size has not changed a lot in these seven years and that it is still between benevolent-authoritative and consultative leadership style. Details of the results, implications of the findings and conclusions are presented and discussed in this paper.
\end{abstract}

